\title{
STATISTICAL ANALYSIS OF ENERGY CONSUMPTION DURING THE CUTTING OF FROZEN MEAT BLOCKS USING MULTIPLE EDGE TOOL
}

\section{СТАТИСТИЧЕСКИИ АНАЛИЗ ЭНЕРГОЗАТРАТ ПРОЩЕССА РЕЗАНИЯ БЛОЧНОГО ЗАМОРОЖЕННОГО МЯСА МНОГОЛЕЗВИЙНЫМ ИНСТРУМЕНТОМ}

\author{
Lisitsyn A.B., Ivashov V.I., Kapovsky B.R., Kozhevnikova O.E. \\ The V.M. Gorbatov All-Russian Meat Research Institute, Moscow, Russia
}

\begin{abstract}
Ключевые слова: измельчение замороженного мяса фрезерование, энергозатрать

\section{Аннотация}

В настоящее время замороженное блочное мясо широко используется в мясоперерабатывающем производстве для выработки колбасных изделий и другой мясной продукиии. Эффективное измельчение замороженного мясного сырья является актуальной задачей для специалистов мясной промьшиленности. В ФГБНУ «ВНИИМП им. В.М. Горбатова» разработан энерго- и ресурсосберегающий проиесс измельчения блоков замороженного мяса методом фрезерования. Определение энергозатрат на измельчение сырья многолезвийным инструментом (фрезами) является важнейшим этапом создания измельчителя нового типа.
\end{abstract}

\section{Введение}

Процесс измельчения сырья является одним из самых энергоемких технологических процессов в мясной промышленности. В ФГБНУ «Всероссийский научно-исследовательский институт мясной промышленности имени В.М. Горбатова» были проведены исследования по созданию инновационного процесса измельчения замороженного блочного мяса методом фрезерования, характеризующегося энерго- и ресурсосбережением $[1,2,3]$.

Основным направлением исследований выбрано изучение применения фрез разной конструкции в качестве рабочего органа измельчителя замороженных мясных блоков. Обосновать такой выбор можно следующими обстоятельствами: 1) при измельчении сырья фрезами площадь контакта режущих кромок с мясом минимальна в сравнении с площадью боковых поверхностей ножей куттера, следовательно, можно обеспечить снижение энергозатрат на трение и адгезию; 2) изменяя параметры процесса измельчения сырья методом фрезерования и применяя сменные фрезы разной конструкции и геометрии, можно влиять на формирование размеров частиц измельченного мяса, обеспечивая заданную степень измельчения сырья при повышении качества готовых мясопродуктов; 3) перерабатывая блоки замороженного мяса промышленных типоразмеров методом фрезерования в одну стадию, можно сократить традиционную технологическую цепочку переработки блочного мяса (блокорезка - волчок - куттер), что обеспечит ресурсосбережение и снижение затрат электроэнергии в расчете на тонну вырабатываемой продукции.

Обработка фрезами различных материалов (металлов, древесины, пластиков и др.) имеет давние

\begin{abstract}
Currently, frozen meat blocks are widely used in meat processing for production of sausages and other meat products. Efficient grinding of frozen raw meat is an urgent task for meat industry professionals. The V.M. Gorbatov All-Russian Meat Research Institute has developed energy-and resource-saving process for grinding of frozen meat blocks by milling. Determination of energy consumption for grinding of raw materials by multiple edge tools (milling tools) is the most important step in the creating of new type mincing machine.
\end{abstract}

\section{Introduction}

The process of raw material grinding is one of the most energy intensive processes in meat industry. The V.M. Gorbatov All-Russian Meat Research Institute has conducted the studies to establish the innovation process for grinding of frozen meat blocks by milling, which is characterized by energy and resource-saving $[1,2,3]$.

The main area of research was the study of different design milling tools as a working element of mincing machine for frozen meat blocks. To justify such choice, the following factors may be used: 1) when grinding the raw material by milling tools the contact area of cutting edges with meat is minimal compared to the area of side surfaces of cutter knives, hence reduced power consumption may be achieved by friction and adhesion reduction; 2) when changing the parameters of raw material grinding process by milling and applying removable milling tools of different design and geometry, we can influence the formation of particle sizes of ground meat providing predetermined degree of raw materials grinding and increasing the quality of finished meat products; 3) when processing the frozen meat blocks of industrial sizes by one-stage milling, it is possible to shorten the traditional workflow of meat blocks processing (block cutting machine - mincing machine cutter), which will ensure resource-saving and reduction of energy consumption per one ton of product.

Processing of different materials (metal, wood, plastic, etc.) by milling tools has a long tradition. Methods of calculation and designing of metal cutting tools, drive mechanisms and other equipment are developed and tested in practice $[4,5]$. However, grinding of frozen meat by multiple edge tools has its own features and has not been studied in full $[1,2,3]$. In particular, it is necessary to determine the energy consumption for the process of frozen meat grinding by milling tools. The results may be used to calculate 
традиции. Разработаны и апробированы на практике методики расчета и проектирования как режущего инструмента, так и приводов механизмов металлорежущих станков и другого оборудования $[4,5]$. Однако измельчение замороженного мяса многолезвийным инструментом имеет свои особенности и в полном объёме ещё не изучено $[1,2,3]$. В частности, необходимо определить энергозатраты на процесс измельчения замороженного мясного сырья фрезами. Полученные результаты могут быть использованы для расчета удельных энергозатрат, приходящихся на единицу площади слоя мяса, снимаемого одновременно режущими зубьями фрезы. Данные этого расчета позволят оценить потребную мощность привода режущего механизма фрезерной машины, предназначенной для измельчения блоков замороженного мяса промышленных типоразмеров.

Замороженные блоки мяса характеризуются существенной неоднородностью по структурному и текстурному признакам. Кроме того, температура сырья перед измельчением неодинакова в глубине блока мяса и на его поверхности. Эти факторы, влияющие на момент сопротивления измельчению как функции времени, и, следовательно, на потребляемую мощность, имеют стохастический характер. В этой связи, целесообразно провести статистический анализ измеренных значений мощности, потребленной приводом механизма резания фрезерного измельчителя [6].

\section{Материалы и методы исследования}

Для исследования одностадийного процесса резания блочного замороженного мяса многолезвийным инструментом была создана экспериментальная установка ИБФ-1 (измельчитель блоков фрезерный модификации 1). Установка комплектовалась фрезами разной конструкции и геометрии. Параметры режима резания (частоту вращения фрезы и скорость подачи сырья в зону измельчения) устанавливали соответствующими настройками преобразователей частоты питающего напряжения, работающих на электродвигатели приводов механизмов резания и подачи установки ИБФ-1. Активную мощность, потребляемую электроприводом механизма резания установки в рабочем режиме, измеряли и фиксировали промышленным анализатором-регистратором АСМ-3192. Токоизмерительные клещи прибора подключали к силовым выводам шкафа управления, комплектующего установку ИБФ-1 (рисунок 1):

Потенциальные провода прибора подсоединяли к фазным выводам статорной обмотки электродвигателя привода механизма резания установки ИБФ-1. Измерения проводили по схеме «три фазы - нейтраль» (рисунок 2): the specific energy consumption per area unit of meat layer removed at the same time by milling tool edges. Data from this calculation will allow to assess the required power for drive of milling machine designed to grind the frozen meat blocks of industrial sizes.

Frozen meat blocks are characterized by significant heterogeneity regarding their structural and textural parameters. Furthermore, the temperature of raw material before grinding is not uniform in the depth and on the surface of the meat block. These factors affecting the resistive torque as functions of time, and therefore affecting the power consumption, have a stochastic character. In this regard, it is appropriate to conduct a statistical analysis of the measured values of power consumed by the drive of milling machine [6].

\section{Materials and methods}

The experimental setup IBF-1 (block milling machine, modification 1) has been developed to study the one-stage process of frozen meat blocks cutting by multiple edge tool. The setup was equipped with milling tools of different design and geometry. Cutting mode settings (milling tool speed and raw material feed rate to the grinding zone) were set by the appropriate adjustment of supply voltage frequency converters accompanying the electric motor drives of IBF-1 cutting and feeding mechanisms. The active power consumed by the electric motor of cutting mechanism in operation mode was measured and recorded by industrial ACM-3192 analyzer-recorder. The instrument clamp devices were connected to the power terminals of IBF-1 control cabinet (Figure 1):

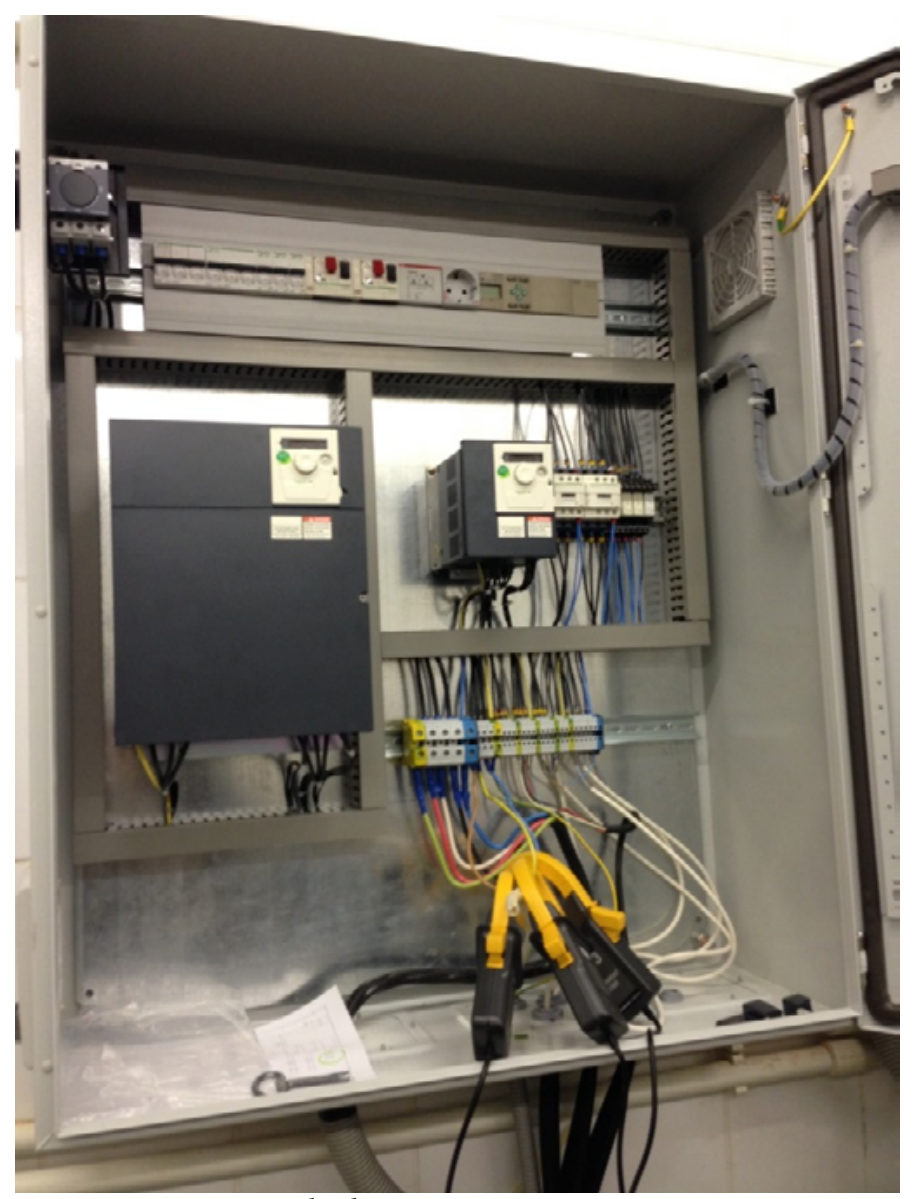

Figure 1 - IBF-1 control cabinet

Рисунок 1 - Шкаф управления установкой ИБФ-1 


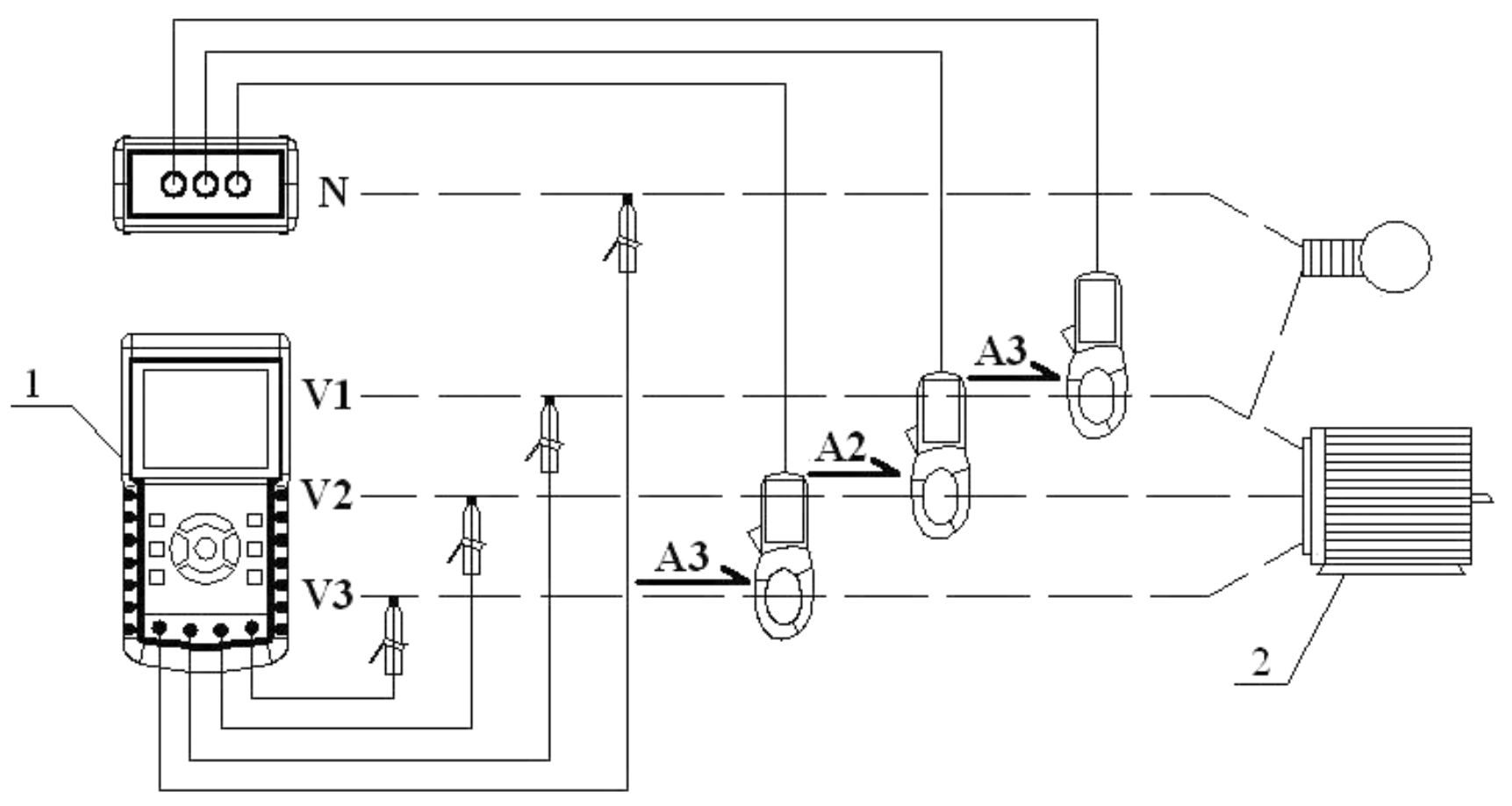

1. ACM-3192 power analyzer

1. Анализатор мощности АСМ-3192

2. Cutting mechanism drive motor

2. Электродвигатель привода механизма резания

Figure 2 - Measurement scheme of active power consumed by IBF-1 cutting mechanism drive motor in operation mode

Рисунок 2 - Схема измерения активной мощности, потребляемой электродвигателем привода механизма резания установки ИБФ-1 в рабочем режиме

На установке измельчали экспериментальные блоки замороженного мяса, нарезанные из блоков промышленного типоразмера (говядины жилованной второго сорта и свинины жилованной полужирной). В соответствии с ГОСТ Р 54704-2011 «Блоки из жилованного мяса замороженные» массовая доля соединительной и жировой ткани в говядине составила не более $20 \%$, в свинине массовая доля жировой ткани составила от $30 \%$ до 50\%. Температура мяса в центре экспериментального блока перед измельчением составляла минус $12^{\circ} \mathrm{C} \ldots$ минус $14^{\circ} \mathrm{C}$.

Статистический анализ энергозатрат процесса измельчения замороженного мяса фрезой проводили методом расчета оценок числовых характеристик (математического ожидания и дисперсии) экспериментального распределения активной мощности, потребляемой электродвигателем привода механизма резания установки ИБФ-1 в процессе измельчения сырья. Проверку соответствия закона экспериментального распределения мощности как случайной величины выдвинутому гипотетическому закону распределения осуществляли по критерию согласия Пирсона.

\section{Результаты и обсуждение}

Данные измерений были получены при измельчении разных экспериментальных блоков замороженного мяса двух видов (говядины и свинины). Общее число замеров мощности (объём выборки) составило 36 значений. Далее данные замеров мощности будем рассматривать как единую статистическую выборку данных. Это обусловлено тем обстоятельством, что статистический анализ потребляемой мощности следует провести для всех случаев экспериментального измельчения фрезой одного типа, комплектующей измельчитель ИБФ-1.
The instrument potential wires were connected to phase terminals of stator winding of IBF-1 cutting mechanism drive motor. The measurements were carried out using «three phases - neutral» model (Figure 2):

The setup grinded the experimental frozen meat blocks derived from industrial size blocks by cutting them (second grade trimmed beef and semi-fat trimmed pork). In accordance with GOST R 54704-2011 «Blocks of frozen trimmed meat», the mass fraction of connective and fat tissue in beef was not more than $20 \%$ and fat tissue mass fraction in pork ranged from $30 \%$ to $50 \%$. The temperature of meat at the center of the experimental block before grinding was minus $12{ }^{\circ} \mathrm{C}$ to minus $14^{\circ} \mathrm{C}$.

Statistical analysis of the energy consumption for frozen meat grinding by milling tool was carried out by calculating estimates of numerical characteristics (mean and variance) of experimental distribution for the active power consumed by IBF-1 cutting mechanism drive motor in the process of raw material grinding. Validation of correspondence of active power experimental distribution as the random variable with the hypothetical distribution law was carried out by the Pearson's fitting criterion.

\section{Results and discussion}

The measurements were obtained in the process of grinding of different experimental frozen meat blocks of two species (beef and pork). The total number of power measurement (sample size) was 36 values. Further details of power measurements will be regarded as a single statistical data sampling. This is due to the fact that the statistical analysis of power consumption should be performed for all cases of experimental grinding using the milling tool of the same type. 
Из данных замеров сформируем группированный статистический ряд (таблица 1).
From these measurements, we will form the grouped statistical series (Table 1).

Table 1. Grouped statistical data series of power consumption measuring for IBF-1 cutting mechanism drive motor (beef, pork) Таблица 1. Группированный статистический ряд данных замеров потребляемой мощности электродвигателем привода механизма резания ИБФ-1 (говядина; свинина)

\begin{tabular}{|c|c|c|c|}
\hline $\begin{array}{l}\text { Range and its limits in kW } \\
\text { Диапазон и его границы в кВт }\end{array}$ & $\begin{array}{c}\text { The number of power } \\
\text { values in the range | Число } \\
\text { значений мощности в } \\
\text { диапазоне }\end{array}$ & $\begin{array}{l}\text { The frequency of entering } \\
\text { the range } p_{i}^{*} \text { | Частота } \\
\text { попадания в диапазон } p_{i}^{*}\end{array}$ & $\begin{array}{l}\text { The average power value in the } \\
\text { range } N_{i c p}, \mathrm{~kW} \mid \text { Среднеe значение } \\
\text { мощности в диапазоне } N_{i c p} \text { кВт }\end{array}$ \\
\hline $\begin{array}{l}\text { Range } 1 ; 1.00 \text { - } 2.00 \\
\text { Диапазон 1; 1,00 - 2,00 }\end{array}$ & 5 & 0.139 & 1.69 \\
\hline $\begin{array}{l}\text { Range } 2 ; 2.00 \text { - } 2.60 \\
\text { Диапазон 2; } 2,00-2,60\end{array}$ & 5 & 0.139 & 2.36 \\
\hline $\begin{array}{l}\text { Range 3; } 2.60 \text { - } 3.20 \\
\text { Диапазон 3; 2,60 - 3,20 }\end{array}$ & 8 & 0.222 & 2.84 \\
\hline $\begin{array}{l}\text { Range 4; } 3.20 \text { - } 3.60 \\
\text { Диапазон 4; 3,20 - 3,60 }\end{array}$ & 8 & 0.222 & 3.42 \\
\hline $\begin{array}{l}\text { Range } 5 ; 3.60 \text { - } 4.40 \\
\text { Диапазон 5; 3,60 - 4,40 }\end{array}$ & 10 & 0.278 & 4.02 \\
\hline
\end{tabular}

По приведенным в таблице 1 данным построим гистограмму численного распределения попаданий величины мощности, потребляемой электродвигателем привода механизма резания установки ИБФ-1, в выбранные диапазоны её значений (рисунок 3).

Рассчитаем плотности частоты по диапазонам значений потребляемой мощности (таблица 2).
According to Table 1, we will plot a histogram of numerical distribution for entering of power consumed by IBF-1 cutting mechanism drive motor into the selected range of its values (Figure 3 ).

We will calculate the frequency density at ranges of power consumption values (Table 2 ).

Table 2. Frequency density at ranges of power consumption values.

Таблица 2. Плотности частоты по диапазонам значений потребляемой мощности.

\begin{tabular}{|c|c|c|c|c|c|}
\hline $\begin{array}{l}\text { Limits of power values range, } \mathrm{kW} \\
\text { Границы диапазона значений мощности, кВт }\end{array}$ & $1.00-2.00$ & $2.00-2.60$ & $2.60-3.20$ & $3.20-3.60$ & $3.60-4.40$ \\
\hline $\begin{array}{l}\text { Frequency density } \times 10^{-2}, \mathrm{~kW}-1 \\
\text { Плотность частоты } \times 10^{-2}, \mathbf{k B T - 1}\end{array}$ & 13.9 & 23.20 & 37.00 & 55.50 & 34.80 \\
\hline
\end{tabular}
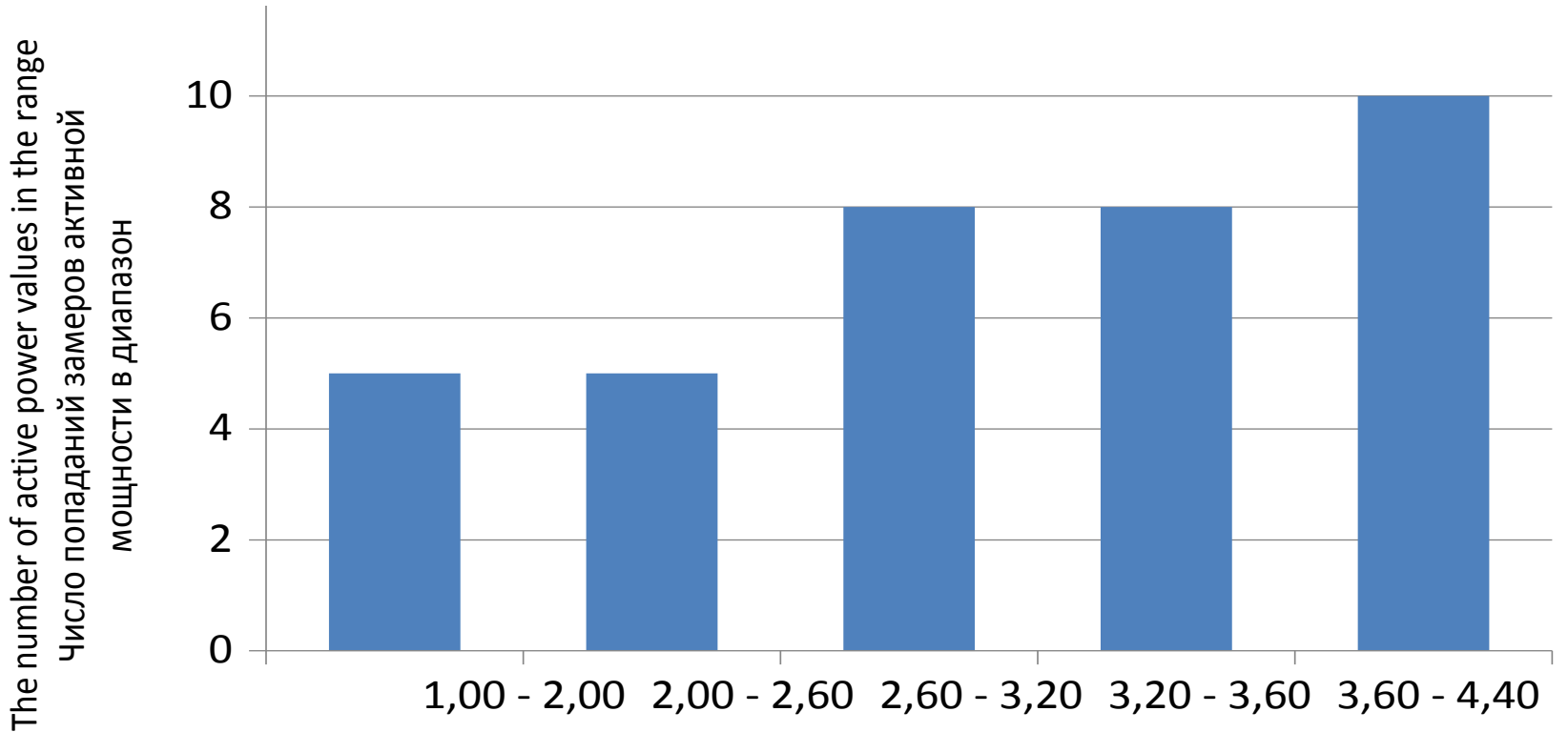

The limits of ranges of active power values, $\mathrm{kW}$ Границы диапазонов значений активнй мощности, кВт

Figure 3 - Histogram of numerical distribution for entering of power consumed by IBF-1 cutting mechanism drive motor into the selected range of its values

Рисунок 3 - Гистограмма численного распределения попаданий величины потребляемой мощности электродвигателем привода механизма резания ИБФ-1 в выбранные диапазоны её значений 
По данным таблицы 2 построим гистограмму плотности частоты распределения мощности, потребляемой в процессе измельчения, в выбранные диапазоны её значений (рисунок 4). В отличие от гистограммы численного распределения попаданий величины мощности в выбранные диапазоны её значений (рисунок 3), здесь мы получаем объективную картину экспериментального распределения мощности как случайной величины, устраняя фактор субъективного выбора границ диапазонов [7]. По виду гистограммы приведенной на рисунке 4 можно предположить, что закон распределения мощности близок к закону Гаусса.

Оценим правдоподобие этой гипотезы расчетным путем. Вычислим оценки числовых характеристик опытного распределения мощности, потребляемой в процессе измельчения:

$$
\begin{gathered}
\mathrm{m}_{\mathrm{N}}^{*}=\sum_{\mathrm{i}=1}^{\mathrm{k}} \mathrm{N}_{\mathrm{icp}} \cdot \mathrm{p}_{\mathrm{i}}^{*}=3,07(\kappa \mathrm{BT}), \\
\sigma_{\mathrm{N}}^{*}=\sqrt{\mathrm{D}_{\mathrm{N}}^{*}}=\sqrt{\alpha_{2}-\left(\mathrm{m}_{\mathrm{N}}^{*}\right)^{2}}=0,789(\text { (кВт), }
\end{gathered}
$$

где $m_{N}^{*}$ - оценка математического ожидания опытного распределения; $\sigma_{N}^{*}$ - оценка среднего квадратического отклонения опытного распределения; $D_{N}^{*}$ оценка дисперсии опытного распределения; $k$ число диапазонов; $p_{i}^{*}$ - частота попадания в $i$-тый диапазон; $N_{i c p}$ - среднее значение мощности в $i$-том диапазоне; $\alpha_{2}$ - начальный момент второго порядка опытного распределения потребляемой мощности в процессе измельчения.

Выдвинем гипотезу, что опытное статистическое распределение потребляемой мощности электродвигателем привода механизма резания измельчителя ИБФ-1 подчиняется нормальному закону с вычисленными выше параметрами:
According to Table 2, we will plot a histogram of the frequency density for distribution of power consumed during the grinding process, in its chosen range of values (Figure 4 ). In contrast to the histogram of the numerical distribution of power values entering the chosen ranges of its values (Figure 3 ), here we can see an objective picture of the experimental power distribution as a random variable eliminating the factor of subjective choice for ranges limits [7]. By referring to the histogram shown in Figure 4 it may be assumed that the power distribution law is close to the Gaussian one.

We will estimate the plausibility of this hypothesis by calculation. Let us calculate estimates of numerical characteristics for experimental distribution of power consumed in the process of grinding:

$$
f(a)=\left[\frac{1}{(\sigma \sqrt{2 \pi})}\right] \cdot \exp \left[-\frac{(a-m)^{2}}{\left(2 \cdot \sigma^{2}\right)}\right]=\left[\frac{1}{(0,789 \cdot \sqrt{2 \pi})}\right] \times \exp \left[-(a-3,07)^{2} /(2 \cdot 0,622)\right]
$$
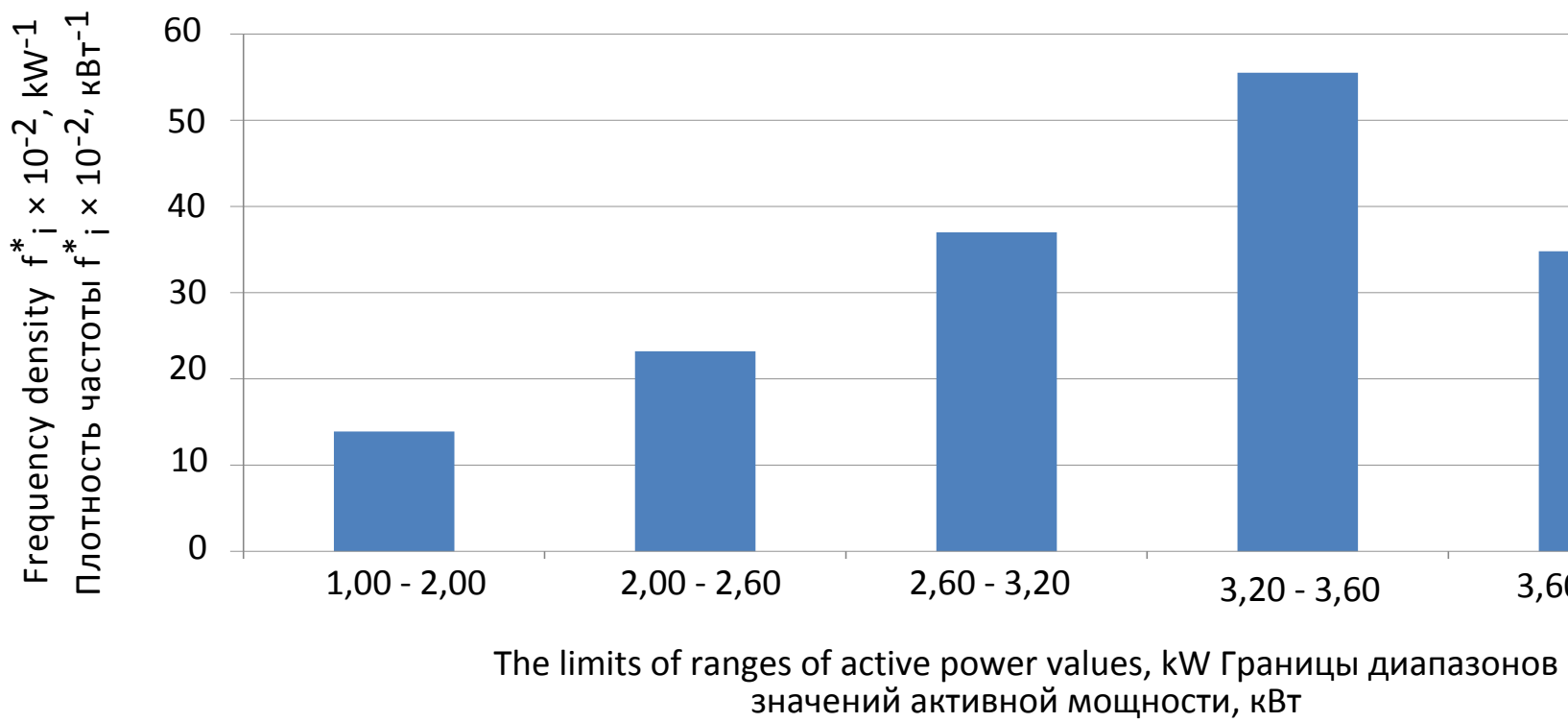

Figure 4 - Histogram of the frequency density for distribution of the power consumed by IBF-1 cutting mechanism drive motor in operation mode - by the ranges of its measured values

Рисунок 4 - Гистограмма плотности частоты распределения мощности, потребляемой электродвигателем привода механизма резания установки ИБФ-1 в рабочем режиме по диапазонам её измеренных значений 
Table 3. The probability of entering the power into the ranges of its values calculated for the hypothetical distribution

Таблица 3. Вероятности попадания значений мощности по гипотетическому распределению в выбранные диапазоны

\begin{tabular}{|l|c|c|c|c|c|}
\hline $\begin{array}{l}\text { Limits of power values range, } \mathrm{kW} \mid \\
\text { Границы диапазона значений мощности, кВт }\end{array}$ & $1.00-2.00$ & $2.00-2.60$ & $2.60-3.20$ & $3.20-3.60$ & $3.60-4.40$ \\
\hline Probability | Вероятность & 0.0824 & 0.1873 & 0.2933 & 0.1811 & 0.2059 \\
\hline
\end{tabular}

Проверку правдоподобия выдвинутой гипотезы осуществим, используя критерий согласия Пирсона.

В таблице 3 приведены вероятности попадания мощности в диапазоны её значений, вычисленные по гипотетическому распределению.

Вычислим значение критерия Пирсона:

$$
\chi^{2}=\sum_{i=1}^{k} \frac{\left(n_{i}-n \cdot p_{i}\right)^{2}}{\left(n \cdot p_{i}\right)} \cong 3.70,
$$

где $i$ - номер диапазона значений мощности; $k$ - число диапазонов; число значений мощности в $i$ - том диапазоне; $\mathrm{n}$ - число измерений $n=36, \sum \mathrm{n}_{\mathrm{i}}=\mathrm{n} ; \quad ; p_{i}$ вероятность попадания значения мощности по гипотетическому распределению в $i$ - тый диапазон.

Табличное значение критерия Пирсона для уровня значимости 0,1 при трех независимых условиях и числе степеней свободы равно $r=k-3=5-3=2$ [8]: $\chi_{\text {табл }}^{2}=4,60$ Таким образом, при принятых условиях рассчитанное значение критерия Пирсона меньше табличного значения $(3,70<4,60)$. Следовательно, гипотезу о нормальном распределении активной мощности, потребляемой электродвигателем привода механизма резания измельчителя ИБФ-1 в процессе измельчения как случайной величины можно считать не противоречащей опытным данным.

Результаты вычислений позволяют предположить на основании центральной предельной теоремы $[7,8]$, что стохастические факторы (неоднородность сырья по текстурному и структурному признакам, изменение температуры сырья в объёме блока мяса) имеют равнозначное влияние на энергозатраты процесса измельчения блочного замороженного мяса по методу фрезерования.

\section{Выводы}

Как видно из результатов статистического анализа опытного распределения активной мощности, потребляемой электродвигателем привода механизма резания установки ИБФ-1 в процессе измельчения, существует значительная дисперсия значений мощности возле оценки математического ожидания мощности. Отметим, что оценка среднего квадратического отклонения мощности составляет примерно 26\% от значения оценки математического ожидания. В этой связи можно сказать, что момент сопротивления измельчению, то есть нагрузка на фрезу в рабочем режиме, существенно изменяется по величине. Это объясняется значительной неоднородностью исходного сырья. При изменении нагрузки на фрезу измельчителя в рабочем режиме изменяется частота её вращения, что приводит к дополнительной дисперсии линейных размеров мясной стружки в связи с изменением параметров режима резания (подачи
We will estimate the plausibility of this hypothesis by using the Pearson's fitting criterion.

Table 3 shows the probability of entering the power into the ranges of its values calculated for the hypothetical distribution.

Let us calculate the Pearson's fitting criterion:

$$
\chi^{2}=\sum_{i=1}^{k} \frac{\left(n_{i}-n \cdot p_{i}\right)^{2}}{\left(n \cdot p_{i}\right)} \cong 3.70
$$

where $i$-number of power values range; $k$-number of ranges; number of power values in $i^{\text {th }}$ range; $n$ - number of measurements, $n=36 \sum_{n_{i}=n} ; p_{i}$ the probability of power value entering into $i^{\text {th }}$ range for a hypothetical distribution.

Tabulated value of Pearson's criterion for significance level 0.1 at three independent conditions and at the number of degrees of freedom is $r=k-3=5-3=2$ [8]: $\chi_{\text {tab }}^{2}=4.60$. Thus, under the assumed conditions, the calculated value is less than the Pearson's criterion tabulated value $(3.70<4.60)$. Therefore, the hypothesis about normal distribution of active power consumed by IBF-1 cutting mechanism drive motor in the process of grinding as a random variable may be regarded as consistent with the experimental data.

On the basis of the central limit theorem $[7,8]$, the calculation results suggest that stochastic factors (raw material heterogeneity regarding texture and structural characteristics, temperature variability in raw meat blocks) have equal influence on the energy consumption in the process of frozen meat blocks grinding by milling.

\section{Conclusion}

As it can be seen from the results of statistical analysis of the experimental distribution of active power consumed by IBF-1 cutting mechanism drive motor in the process of grinding, there is a significant variance of values near the mean estimates for power. It must be noted that the estimate of standard deviation for power is about $26 \%$ of the mean estimate. In this regard, it can be assumed that the resistive torque, i.e. the load on the milling tool in operation mode, varies considerably. This is due to significant raw material heterogeneity. When the load on the milling tool in operation mode changes the frequency of its rotation changes too, which leads to further dispersion of the linear dimensions of chipped meat due to changes in cutting mode parameters (feed onto the milling tool edge and cutting speed). Taking this into account, it is necessary to ensure the stabilization of the cutting mode parameters by the means of automatic control system (ACS) during the grinding in operation mode $[9,10,11]$. The ACS structure for frozen raw meat grinding process by milling tool using a control computer is proposed in [12]. 
на зуб фрезы и скорости резания сырья). Учитывая это, следует обеспечить стабилизацию параметров режима резания средствами системы автоматического управления (САУ) процессом измельчения в рабочем режиме измельчителя $[9,10,11]$. Структура САУ процессом измельчения замороженного мясного сырья фрезой с использованием управляющей вычислительной машины предложена в работе [12].

Установленный статистическим анализом факт нормального распределения значений энергозатрат процесса измельчения сырья методом фрезерования, полученных экспериментальным путем, позволяет использовать вычисленную оценку математического ожидания потребленной активной мощности 3,07 кВт для расчета установленной мощности привода механизма резания фрезерной машины, предназначенной для измельчения блоков замороженного мяса промышленных типоразмеров.

\section{БЛБЛИОГРАФИЧЕСКИЙ СПИСОК}

1. Ивашов, В.И. Современная практика переработки замороженного мясного сырья. [Текст] // В.И. Ивашов, А.Н. Захаров, А.Б. Аисицын, Б.Р. Каповский, О.Е. Кожевникова // Все о мясе. -2014, -№ 2. -c.24-29

2. Иисицын, А.Б. Измельчение замороженного блочного мяса методом фрезерования [Текст] / А.Б. Мисицын, В.И. Ивашов, А.Н. Захаров, Б.Р. Каповский, А.А. Максимов // Всё о мясе. - 2013. - № 4. - C.42 - 48.

3. Иисицын, А.Б. Интемектуальная система управления качеством мясных фаршей [Текст] / А.Б. Мисицын, В.И. Ивашов, А.Н. Захаров, Б.Р. Каповский, О.Е. Кожевникова // Всё о мясе. - 2013. - № 6. - С.32 - 38.

4. Иноземцев, Г.Г. Проектирование метаморежущих инструментов / Г.Г. Иноземцев. - М. «Машиностроение", 1984. - 272 с.

5. Кряжев, Н.А. Фрезерование древесины / Н.А. Кряжев. М.: Лесная промышленность, 1979. - 200 с.

6. Белов, М.П. Автоматизированный электропривод типовых производственных механизмов и технологических комплексов / М.П. Белов, В.А. Новиков, М.Н. Рассудов. - М.: Издательский центр "Академия", 2004. - 576 с.

7. Кобзарь, А.И. Прикладная математическая статистика. Аля инженеров и научных работников / А.И. Кобзарь. - М.: ФИЗМАЛИТ, 2006. - 816 c.

8. Вентцель, Е.С. Теория верояпностей и её инженерные приложения / Е.С. Вентцель, М.А. Овчаров. - М.: "Наука", 1988. - 480 с.

9. Пупков, К.А. Методы классической и современной теории автоматического управления. Том 2. Статистическая Аинамика и идентификация систем автоматического управления / К.А. Пупков, Н.А. Егупов, Е.М. Воронов и Ар.; поА ред. К.А. Пупкова, Н.А. Егупова. - М.: Издательство МГТУ им. Н.Э. Баумана, 2004. -640 c.

10. Aktuelles aus der Fleischforschung Kurzfassungen der Fachvortzge von der 49 Kulmbacher Wochevom 6. bis. 8 // Fleischwirtschaft. - 2014. - № 6. - s.84.

11. Computer technology improves the efficiency of processing // Meat International. - 2004. - № 2. - p.22.

12. Максимов, АА. Автоматическое управление процессом тонкого измельчения мясного сырья [Текст] /АА. Максимов, Б.Р. Каповский, А.Н. Захаров // Мясная индустрия. - 2013. - № 1. - С.42 - 46.
Statistical analysis established the fact of normal distribution for energy consumption values during raw material grinding process by milling obtained experimentally. This allows to use the calculated estimate of mean consumed active power of $3.07 \mathrm{~kW}$ to calculate rated power for cutting mechanism drive of milling machine designed for grinding of frozen meat blocks of industrial sizes.

\section{REFERENCES}

1. Ivashov, V.I. The current practice of frozen raw meat processing. [Text] // V.I. Ivashov, A.N. Zakharov, A.B. Lisitsyn, B.R. Kapovsky, O.E. Kozhevnikova // All about meat. - 2014, - No. 2. - p. 24 - 29.

2. Lisitsyn A.B. Grinding of frozen meat blocks by milling [Text] / A.B. Lisitsyn, V.I. Ivashov, A.N. Zakharov, B.R. Kapovsky, D.A. Maksimov // All about meat. - 2013. No. 4 . - p. 42 - 48.

3. Lisitsyn A.B. Intelligent quality control system for minced meat [Text] / A.B. Lisitsyn, V.I. Ivashov, A.N. Zakharov, B.R. Kapovsky, O.E. Kozhevnikova // All about meat. - 2013. No. 6. - p. 32 - 38.

4. Inozemtsev, G.G. Design of metal cutting tools / G.G. Inozemtsev. - M. "Mashinostroenie", 1984. - 272 p.

5. Kryazhev, N.A. Milling of wood / N.A. Kryazhev. - M.: The forest industry, 1979. - $200 \mathrm{p}$.

6. Belov, M.P. Automatic electric motor drive for typical industrial machinery and technological systems / M.P. Belov, V.A. Novikov, L.N. Rassudov. - M.: Publishing Center "Akademia", 2004. - 576p.

7. Kobzar, A.I. Applied mathematical statistics. For engineers and scientists / A.I. Kobzar. - M.: FIZMALIT, 2006. - 816 p.

8. Wentzel, E.S. Probability theory and its engineering applications / E.S. Wentzel, L.A. Ovcharov. M.: "Nauka", 1988. - 480 p.

9. Pupkov K.A. Methods of classical and modern automatic control theory. Volume 2. Statistical dynamics and identification of automatic control systems / K.A. Pupkov, N.D. Egupov, E.M. Voronov, etc.; edited by K.A. Pupkov, N.D. Egupov. - M.: Publishing Center of Bauman Moscow State Technical University, 2004. - $640 \mathrm{p}$.

10.Aktuelles aus der Fleischforschung Kurzfassungen der Fachvortzge von der 49 Kulmbacher Wochevom 6. bis. $8 / /$ Fleischwirtschaft. - 2014. - No. 6. - p. 84.

11. Computer technology improves the efficiency of processing // Meat International. - 2004. - No. 2. - p. 22.

12. Maksimov, D.A. Automatic control of the process of raw meat fine grinding [Text] / D.A. Maksimov, B.R. Kapovsky, A.N. Zakharov // Meat Industry. - 2013. - No. 1. - p. 42 - 46. 


\section{СВЕДЕНИЯ ОБ АВТОРАХ}

Принадлежность к организации

Лисицын Андрей Борисович - доктор технических наук, профессор, академик РАН, директор ФГБНУ «Всероссийский научно-исследовательский институт мясной промышленности имени В.М. Горбатова», 109316, г. Москва, ул. Талалихина,26 Тел.: 8(495)676-95-11 e-mail: info@vniimp.ru

Ивашов Валентин Иванович - доктор технических наук, профессор, академик $\mathrm{PAH}$, главный научный сотрудник ФГБНУ «Всероссийский научноисследовательский институт мясной промышленности имени В.М. Горбатова», 109316, г. Москва, ул. Талалихина,26 Тел.: 8(495)676-67-51 e-mail: info@vniimp.ru

Каповский Борис Романович - старший научный сотрудник лаборатории «Систем машин, развития новой техники и опытного конструирования» ФГБНУ «Всероссийский научноисследовательский институт мясной промышленности имени В.М. Горбатова», 109316, г. Москва, ул. Талалихина,26 Тел.: 8(495)676-67-51 e-mail: system@vniimp.ru

Кожевникова Ольга Евгеньевна - младший научный сотрудник лаборатории «Систем машин, развития новой техники и опытного конструирования» ФГБНУ «Всероссийский научноисследовательский институт мясной промышленности имени B.М. Горбатова», 109316, г. Москва, ул. Талалихина,26 Тел.: 8(495)676-67-51 e-mail: system@vniimp.ru

\section{Критерии авторства}

Авторы в равных долях имеют отношение к написанию рукописи и одинаково несут ответственность за плагиат

\section{Конфликт интересов}

Авторы заявляют об отсутствии конфликта интересов

Поступила 21.12.2015

\section{AUTHOR INFORMATION}

Affiliation

Lisitsyn Andrey Borisovich - doctor of technical sciences, professor, academician of the Russian Academy of Sciences, Director of The V.M. Gorbatov All-Russian Meat Research Institute, 109316, Moscow, Talalikhina str., 26

Ph.: 8 (495) 676-95-11 e-mail: info@vniimp.ru

Ivashov Valentin Ivanovich - doctor of technical sciences, professor, academician of the Russian Academy of Sciences, chief research scientist of The V.M. Gorbatov All-Russian Meat Research Institute, 109316, Moscow, Talalikhina str., 26

Ph.: 8 (495) 676-67-51 e-mail: info@vniimp.ru

Kapovsky Boris Romanovich - senior research scientist, Laboratory of systems of cars, development of new technics and skilled designing, The V.M. Gorbatov All-Russian Meat Research Institute, 109316, Moscow, Talalikhina str., 26

Ph.: 8 (495) 676-67-51 e-mail: system@vniimp.ru

Kozhevnikova Olga Evgenievna - junior research scientist, Laboratory of systems of cars, development of new technics and skilled designing, The V.M. Gorbatov All-Russian Meat Research Institute, 109316, Moscow, Talalikhina str., 26

Ph.: 8 (495) 676-67-51 e-mail: system@vniimp.ru

\section{Contribution}

Authors equally contributed to the writing of the manuscript and are equally responsible for plagiarism

\section{Conflict of interest}

The authors declare no conflict of interest

Received 21.12.2015 